\title{
ВИВЧЕННЯ РІВНЯ ПРОДУКТІВ ОКИСНОЇ МОДИФІКАЦЇ̈ БІЛКІВ ТА ФЕРМЕНТІВ АНТИОКСИДАНТНОГО ЗАХИСТУ У ХВОРИХ 3 ПІСЛЯОПЕРАЦІЙНИМ ГІПОПАРАТИРЕОЗОМ
}

ДВНЗ «Івано-Франківський національний медичний університет»

\begin{abstract}
Резюме. В основу дослідження покладено результати комплексного обстеження і лікування 70 осіб із хірурургічною патологією щитоподібної залози (ЩЗ), які перебували на стаціонарному лікуванні в хірургічному відділенні Івано-Франківської центральної міської клінічної лікарні та в Івано-Франківському обласному онкологічному диспансері з 2013 по 2016 роки. Всім хворим проводили визначення рівнів паратгормону, загального та іонізованого кальцію, визначали оптичну щільність продуктів окисної модифікації білків (ОМБ), активність ферментів антиоксидантної системи (АОС) каталази і супероксиддисмутази.

У післяопераційному періоді в пацієнтів, оперованих із приводу захворювань Щ3, спостерігалося підвищення продуктів ОМБ на тлі зниження ферментів анти-
\end{abstract}

Вступ. Операції на щитоподібній залозі (ЩЗ) належать до технічно складних хірургічних втручань. Це зумовлено анатомічними взаємовідношеннями Щ3 з органами шиї $[7,12]$. Стандартними ситуаціями в хірургії ЩЗ є збереження неушкодженими нервів гортані і паращитоподібних залоз (ПщЗ). Проте саме вони були, і, на жаль, залишаються ахіллесовою п'ятою хірургії цього органа $[5,9]$.

Одним із важливих ускладнень при хірургічному лікуванні хворих на захворювання ЩЗ у післяопераційному періоді $\epsilon$ гіпопаратиреоз (ГПТ), частота якого коливається від 0,5\% до 4,8\%. Виникаюча при стійких та транзиторних ГПТ гіпокальціємія, є частим ускладненням та становить до $63 \%$ [2, 14]. Післяопераційний ГПТ iз більшою імовірністю виникає в пацієнтів, які перенесли кілька операцій у ділянці шиї або у випадках, коли проводиться тиреоїдектомія в поєднанні з лімфодисекцією. За рахунок значної травматизації відбувається пошкодження чи порушення кровопостачання ПЩЗ, що призводить до ішемії та гіпоксії залоз [13].

Зважаючи на універсальну роль окисного стресу як чинника ушкодження клітин, є підстави вважати, що порушення структурної цілісності ПщЗ можуть бути опосередковані активацією процесів вільнорадикального окиснення $[4,10]$.

Встановлено, що за умов окисного стресу активні форми кисню (АФК) пошкоджують усі біологічні структури, але донедавна головну увагу під час вивчення модифікуючої дії АФК приділяли ліпідам. Нині інтерес дослідників підвищився до вивчення механізмів взаємодії АФК із білками. Показано, що при ряді патологічних станів саме білки, а не ліпіди та нуклеїнові кислоти, є ефективними пастками генерованих АФК, i їx окисна модифікація розглядається як один із ран- оксидантного захисту (АОЗ). Встановлено, що дисбаланс системи ОМБ-АОЗ поглиблюється в пацієнтів із наявністю ознак гіпопаратиреозу (ГПТ). Встановлено, що максимальне підвищення продуктів ОМБ відбувається в осіб на 1-шу добу післяопераційного періоду, тоді як максимальне зниження ферментів АОЗ відзначається в пацієнтів на 6-7-му добу, що вказує на важливу роль окисного стресу в патогенезі післяопераційного ГПТ. Перспективним напрямком комплексної терапії хворих $з$ ознаками післяопераційного ГПТ є застосування препаратів з антиоксидантною дією.

Ключові слова: операції на щитоподібній залозі, гіпопаратиреоз, окисна модифікація білків, каталаза, супероксиддисмутаза.

ніх і надійних маркерів оксидативного стресу [3, 6]. Встановлено, що за умов окисного стресу й надмірної генерації АФК розвиваються процеси неконтрольованої модифікації білків, які спричиняють фрагментацію білків, їхню денатурацію, а також утворення первинних амінокислотних радикалів, що далі вступають у вторинну взаємодію із сусідніми амінокислотними залишками, а це в цілому створює досить складну картину пошкоджувальної дії АФК на білкові макромолекули. Все це призводить до втрати білками їхньої біологічної активності й порушення обмінних, зокрема регенеративних процесів $[3,6,10]$. На думку дослідників, кисневозалежне окиснення білків $€$ раннім індикатором пошкодження органів i тканин, а процеси ОМБ при всіх патологічних станах повинні перебувати під безперервним лабораторним контролем $[4,10]$.

У той же час, для знешкодження негативної дії АФК на мембрани клітин, в організмі існує та функціонує антиоксидантна система (АОC) захисту, що об'єднує у своєму понятті декілька етапів знешкодження надлишків АФК: знешкодження кисневих радикалів (супероксиддисмутаза (СОД), церулоплазмін, токоферол та інші), інгібування впливу перекисів на мембранні структури (пероксидази, каталаза $(\mathrm{K}))$ : ензимне відновлення гідроперекисів, мембранозв'язаних білків та ліпідів $[1,6,10]$.

Отже, у цілому, функціонування АОС захисту, з одного боку, є складовою неспецифічного захисту клітин та тканин від шкідливого та руйнівного впливу АФК, з іншого - разом з оцінкою активності процесів ОМБ - є однією зі складових характеристик клітинного імунітету [6].

Виходячи 3 цих теоретичних положень, важливим $є$ комплексне вивчення процесів ОМБ та АОС як складових неспецифічної резистентності 
організму та, особливо, їх імовірної ролі в розвитку післяопераційного ГПТ.

Мета дослідження. Дослідити рівні продуктів ОМБ та ферментів АОС в осіб, оперованих із приводу захворювань ЩЗ.

Матеріал і методи. В основу дослідження покладено результати комплексного обстеження і лікування 70 осіб із різною патологією ЩЗ, які перебували на стаціонарному лікуванні в хірургічному відділенні Івано-Франківської центральної міської клінічної лікарні та в ІваноФранківському обласному онкологічному диспансері з 2013 по 2016 роки. Серед обстежених було 46 жінок (65,7 \%; 95 \% ДІ 53,4-76,7\%) та 24 чоловіки (34,3 \%; 95 \% ДІ 23,3-46,6 \%). Гемітиреоїдектомія проведена 26 із 70 хворих $(37,1 \%$; 95 \% ДІ 25,9-49,5\%), 16 із 70 хворих (22,9\%; $95 \%$ ДІ 13,7-34,4 \%) проведена субтотальна резекція частки ЩЗ, 14 із 70 хворих (20,0 \%; 95 \% ДІ 11,4$31,3 \%$ - тиреоїдектомія, 14 із 70 хворих (20,0\%; 95 \% ДІ 11,4-31,3 \%) - тиреоїдектомія із центральною та периферичною лімфодисекцією.

Визначення продуктів ОМБ у сироватці крові проводили за допомогою реакції білків із 2,4динітрофенілгідразином (2,4-ДФГ). Оптичну густину утворених динітрофенілгідразинів реєстрували на спектрофотометрі СФ-16. У результаті реакції окиснення білків можуть утворюватися альдегідові і кетонові групи амінокислотних залишків, які взаємодіють з 2,4-ДФГ.

Для аліфатичних кетон-динітрофенілгідразинів нейтрального характеру спектр поглинання 353-377 нм, основного характеру - 430-434 і 524535 нм. 2,4-динітрофенілгідразини, які утворилися, реєстрували при наступних довжинах хвиль: $356,370,430$ i 530 нм [8].

Принцип визначення К за А. Бахом і С. Зубковою базувався на тому, що до проби, яка міс- тить фермент, добавляють певну кількість перекису водню і після певного інтервалу часу за допомогою титрування перманганатом калію встановлюють кількість незруйнованого перекису. Каталазне число крові здорової дорослої людини коливається в межах 9,52-12,92 мг перекису водню на 1 мл крові $\left(\mathrm{MгH}_{2} \mathrm{O}_{2} /\right.$ мл) $[8,10]$.

Принцип визначення СОД базується на відновленні нітротетразолію супероксидними радикалами, які утворюються при реакції між феназинметасульфатом і відновленою формою нікотинаміддинуклеотиду (NAD·H). Один процент блокування утворення нітроформазану ми приймали за 1 умовну одиницю (ум.од.). Активність СОД здорової людини коливається від 60 до 80 ум. од. [8].

Статистичне опрацювання отриманих результатів проводили з використанням стандартного пакета програм «Statistica 6.0 for Windows» (StatSoft, США). Розподіл кожної з досліджуваних змінних був перевірений «на нормальність» методом Шапіро-Вілкса. Для опису змінних із нормальним розподілом використовували середнє арифметичне значення (М) та середнє квадратичне відхилення (s). Опис змінних, розподіл яких відрізнявся від нормального, здійснено за допомогою медіани (Me) та нижнього і верхнього квартилів (q1 і q3). Оцінка достовірності розбіжностей середніх величин для вибірок із нормальним розподілом проведена 3 використанням критерію Стьюдента. При порівнянні у двох незалежних групах показників, розподіл яких не відповідав закону нормальності, використано критерій Манна-Уітні. Критичний рівень значущості (р) при перевірці статистичних гіпотез у даному дослідженні приймали рівним 0,05.

Результати дослідження та їх обговорення. Оскільки процеси ОМБ відіграють ключову роль

Таблиця 1

Показники окиснювальної модифікації білків у паціснтів, оперованих із приводу захворювань щитоподібної залози, М \pm s

\begin{tabular}{|c|c|c|c|}
\hline Довжина хвилі, нм & $\begin{array}{c}\text { Контрольна група } \\
(\mathrm{n}=25) \\
\text { од. опт. густ. } \\
\end{array}$ & $\begin{array}{l}\text { Хворі без ознак } \\
\text { ГПТ }(\mathrm{n}=17) \\
\text { од. опт. густ. } \\
\end{array}$ & $\begin{array}{c}\text { Хворі з ознаками ГПТ } \\
(\mathrm{n}=53) \\
\text { од. опт. густ. } \\
\end{array}$ \\
\hline $\mathrm{OMБ}_{356}$ & $1,158 \pm 0,234$ & $\begin{array}{c}1,878 \pm 0,143 \\
\mathrm{p}<0,01\end{array}$ & $\begin{array}{c}2,378 \pm 0,224 \\
\mathrm{p}<0,001 \\
\mathrm{p}_{1}<0,05\end{array}$ \\
\hline $\mathrm{OMБ}_{370}$ & $1,221 \pm 0,118$ & $\begin{array}{c}2,025 \pm 0,203 \\
\mathrm{p}<0,05\end{array}$ & $\begin{array}{c}2,646 \pm 0,274 \\
\mathrm{p}<0,001 \\
\mathrm{p}_{1}<0,05\end{array}$ \\
\hline $\mathrm{OMБ}_{430}$ & $0,561 \pm 0,119$ & $\begin{array}{c}1,245 \pm 0,185 \\
\mathrm{p}<0,05\end{array}$ & $\begin{array}{c}1,725 \pm 0,212 \\
\mathrm{p}<0,001 \\
\mathrm{p}_{1}<0,05\end{array}$ \\
\hline $\mathrm{OMБ}_{530}$ & $0,104 \pm 0,027$ & $\begin{array}{c}0,174 \pm 0,018 \\
\mathrm{p}<0,05\end{array}$ & $\begin{array}{c}0,451 \pm 0,025 \\
\mathrm{p}<0,01 \\
\mathrm{p}_{1}<0,05\end{array}$ \\
\hline
\end{tabular}

Примітка. p - достовірність різниці показників ОМБ у пацієнтів, оперованих із приводу захворювань ЩЗ з та без ознак ГПТ порівняно з групою контролю; $\mathrm{p}_{1}$ - достовірність різниці показників ОМБ у пацієнтів, оперованих із приводу захворювань ЩЗ з ознаками ГПТ порівняно з хворими без ознак ГПТ; $\mathrm{n}$ - кількість обстежених 
Таблиця 2

Вміст каталази та супероксиддисмутази у сироватці крові паціснтів, оперованих 3 приводу захворювань щитоподібної залози, Ме (q1; q3)

\begin{tabular}{|c|c|c|c|}
\hline Показник & $\begin{array}{c}\text { Контрольна група } \\
\mathrm{n}=25\end{array}$ & $\begin{array}{c}\text { Хворі без ознак } \\
\text { ГПТ, } \mathrm{n}=17\end{array}$ & $\begin{array}{c}\text { Хворі з ознаками } \\
\text { ГПТ } \\
\mathrm{n}=53\end{array}$ \\
\hline К, мг $\mathrm{H}_{2} \mathrm{O}_{2} /$ мл & $11,82(10,42 ; 12,45)$ & $\begin{array}{c}8,07(7,58 ; 8,87) \\
\mathrm{p}<0,01\end{array}$ & $\begin{array}{c}5,23(4,54 ; 5,93) \\
\mathrm{p}<0,001 \\
\mathrm{p}_{1}<0,001\end{array}$ \\
\hline СОД, ум. од. & $67,00(65,45 ; 68,56)$ & $\begin{array}{c}43,45(38,68 ; 46,47) \\
\mathrm{p}<0,001\end{array}$ & $\begin{array}{c}27,45(18,72 ; 36,14) \\
\mathrm{p}<0,001 \\
\mathrm{p}_{1}<0,001\end{array}$ \\
\hline
\end{tabular}

Примітка. p - достовірність різниці показників ОМБ у пацієнтів, оперованих із приводу захворювань ЩЗ з та без ознак ГПТ порівняно з групою контролю; $\mathrm{p}_{1}$ - достовірність різниці показників ОМБ у пацієнтів, оперованих із приводу захворювань ЩЗ з ознаками ГПТ порівняно з хворими без ознак ГПТ; n - кількість обстежених

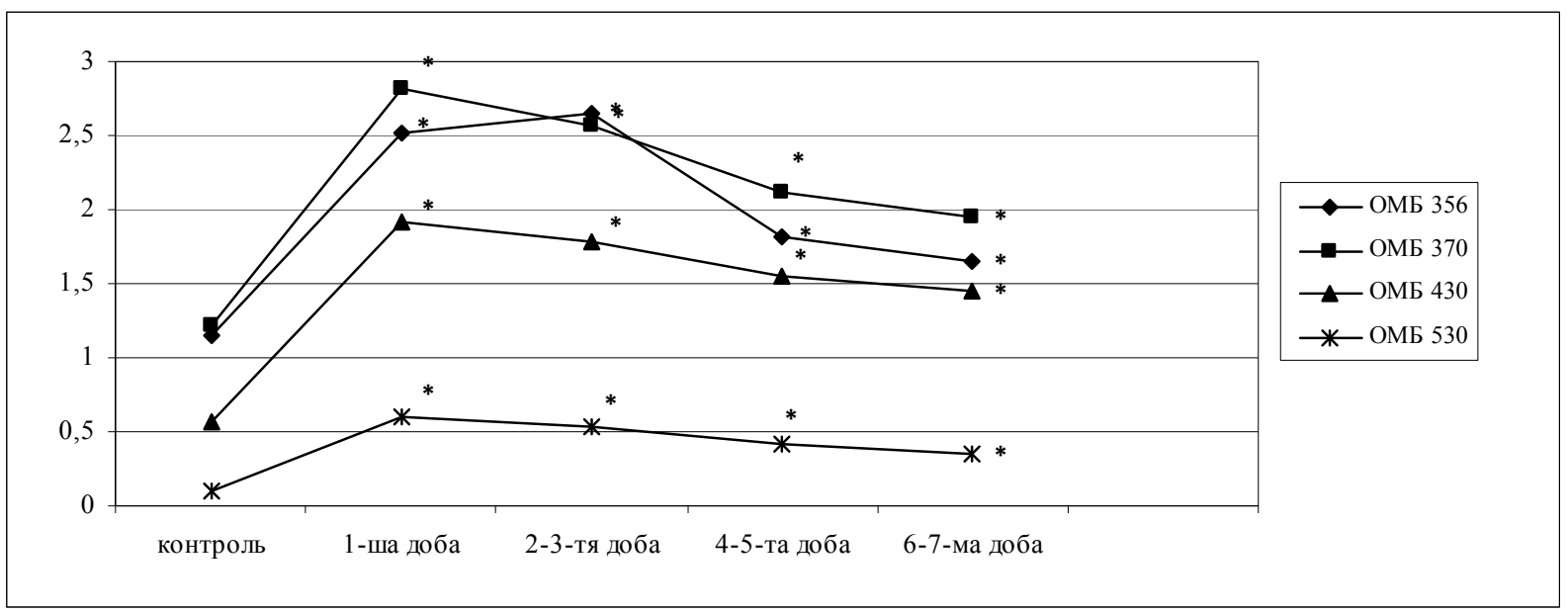

Рис. 1. Показники окисної модифікації білків залежно від доби післяопераційного періоду

Примітка. *- вірогідність різниці порівняно з групою контролю $(\mathrm{p}<0,05)$

у молекулярних механізмах оксидативного стресу і $є$ пусковими факторами окиснювальної деструкції інших молекул (ліпіди, ДНК) дослідження даних показників набуває пріоритетного значення. У 53 (75,7 \%; 95 \% ДІ 64,0-85,2 \%) пацієнтів ми відзначили достовірне зниження рівня іонізованого Са і паратгормону на 1-шу добу післяопераційного періоду $(\mathrm{p}<0,05)$, тобто ми виявили в них ознаки гіпопаратиреозу.

Про інтенсивність процесів пероксидації білків судили за оптичною густиною аліфатичних альдегідо- і кетонопохідних динітрофенілгідразинів нейтрального i основного характеру $\left(\mathrm{OMБ}_{356}, \mathrm{OMБ}_{370}, \mathrm{OMБ}_{430}, \mathrm{OMБ}_{530}\right)$.

Встановлено, що у пацієнтів після операції на ЩЗ відбувається вірогідне зростання інтенсивності ОМБ. Ми виявили, що початковий рівень аліфатичних альдегідо- і кетонопохідних динітрофенілгідразинів основного характеру був нижчим, ніж нейтрального. Виявлено достовірне зростання ОМБ ${ }_{356}$ та ОМБ $_{370}$ У пацієнтів без ознак ГПТ - в 1,62 та в 1,66 раза, ОМБ 430 та ОМБ $_{530}-$ у 2,22 та 1,67 раза порівняно 3 контролем $(\mathrm{p}<0,05)$. Проте ми відзначили достовірно вищі показники ОМБ у пацієнтів з ознаками ГПТ порівняно 3 особами без ознак ГПТ, так ОМБ 356 та ОМБ 370 У хворих на СДС із МК-в 1,26 та в 1,31 раза, $\mathrm{OMБ}_{430}$ та $\mathrm{OMБ}_{530}$ - в 1,39 та 2,59 раза $(\mathrm{p}<0,05)$ (табл.1). Таким чином, у пацієнтів, оперованих із приводу захворювань ЩЗ, відмічено підвищення процесів ОМБ, що є захисною реакцією та призводить до руйнування патологічно змінених білків із подальшим виведенням їх з організму. Однак при пролонгації активності ОМБ відбувається їх денатурація, руйнування ферментних систем та лізис клітини, що, у свою чергу, може сприяти пошкодженню клітин ПщЗ $[6,11]$.

Вивчення механізмів функціонування АОС дає можливість регулювати процеси перекисного окиснення ліпідів та ОМБ. АОС включає високомолекулярні (СОД, глутатіонпероксидаза і каталаза, глутатіонредуктаза та глутатіонзалежні трансферази) i низькомолекулярні антиоксиданти (відновлений глутатіон, вітаміни Е, C, А і каротиноїди та ін.) [6]. СОД $є$ внутрішньоклітинним ферментом, який бере участь у реакціях дисмутації супероксидного аніон-радикала. К каталізує розщеплення пероксиду водню, який утворюється в результаті дії СОД і органічних гідропероксидів ліпідів [10]. 


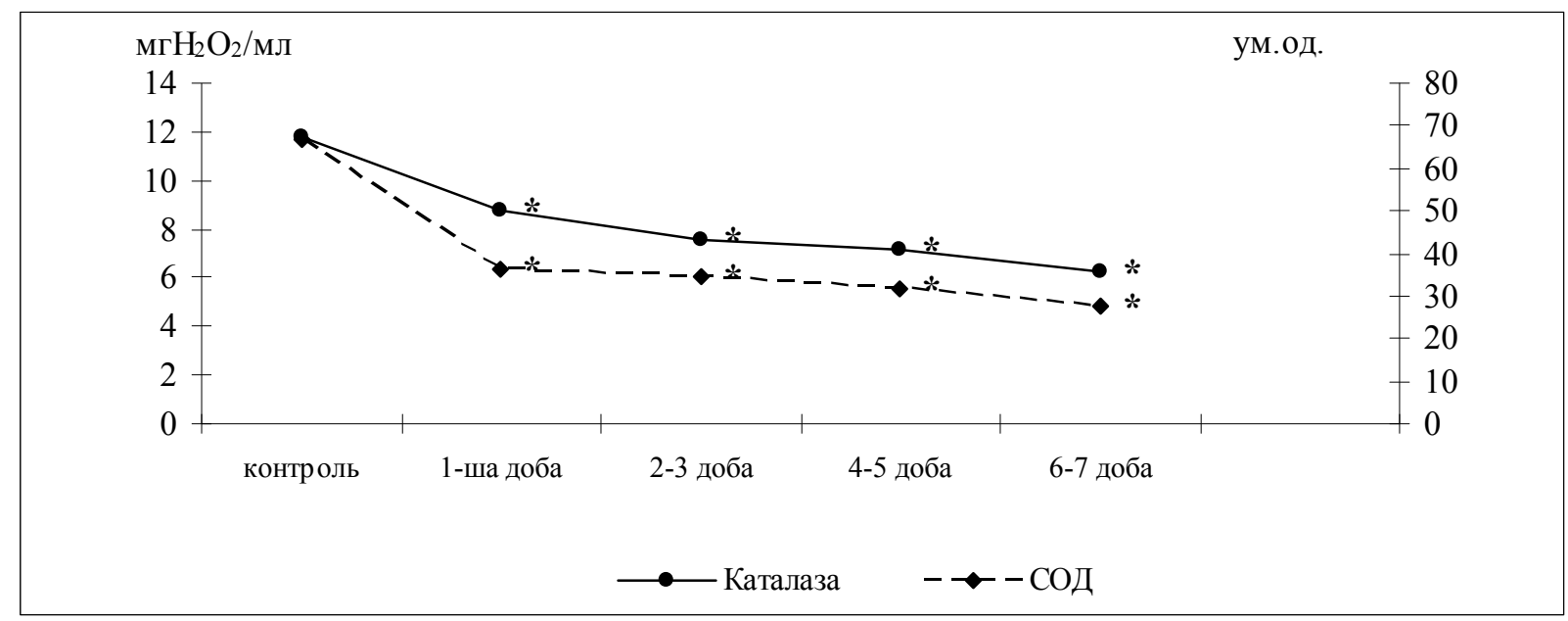

Рис. 2. Показники антиоксидантного захисту залежно від доби післяопераційного періоду

Примітка. * - вірогідність різниці порівняно з групою контролю $(\mathrm{p}<0,05)$

Нами проведено визначення стану АОС у пацієнтів, оперованих із приводу захворювань Щ3 (табл. 2).

Ми встановили достовірне зниження ферментів АОС у пацієнтів, оперованих на Щ3, як з, так і без наявності ознак ГПТ. Так, рівень К у пацієнтів без ознак ГПТ був нижчий в 1,46 раза, а СОД - в 1,54 раза порівняно з контролем ( $<<0,01$; $\mathrm{p}<0,001)$. Ми відзначили достовірно нижчі показники ферментів АОС у групі хворих із наявністю ознак ГПТ. Так, рівень К був нижчий в 1,54 раза, а СОД - в 1,58 раза порівняно з групою пацієнтів без ознак ГПТ $\left(\mathrm{p}_{1}<0,01 ; \mathrm{p}_{1}<0,001\right)$.

Ми проаналізували залежність рівня продуктів ОМБ від часу, який пройшов після операції.

Отримані результати вказують, що вміст продуктів ОМБ найбільше зростав у пацієнтів одразу після операції. На 6-7-му добу рівень продуктів ОМБ наближався до значень групи норми (рис. 1).

Аналізуючи активність системи АО3 залежно від ступеня МК, можна стверджувати, що при збільшенні часу післяопераційного періоду відбувається зниження рівнів антиоксидантних ферментів (рис. 2).

Так, порівняно з контролем, рівень К і СОД у хворих на 1-шу добу достовірно був вищим порівняно $з$ іншими групами $(\mathrm{p}<0,05)$. Рівень $\mathrm{K}$ i СОД достовірно відрізнявся у всіх групах $(\mathrm{p}<0,05)$ і зменшувався зі збільшенням термінів післяопераційного періоду. Безумовно, це є реакцією на тривале підвищення вільнорадикальних процесів, яке призводить до виснаження ферментів АОЗ організму.

\section{Висновки}

1. У післяопераційному періоді у пацієнтів, оперованих з приводу захворювань щитоподібної залози, простежується підвищення продуктів окисної модифікації білків на тлі зниження ферментів антиоксидантного захисту. Встановлено, що дисбаланс системи окисної модифікації біл- ків- антиоксидантного захисту поглиблюється в осіб із наявністю ознак гіпопаратиреозу.

2. Встановлено, що максимальне підвищення продуктів окисної модифікації білків відбувається у пацієнтів на 1-шу добу післяопераційного періоду, тоді як максимальне зниження ферментів антиоксидантного захисту відзначається у хворих на 6-7-му добу, що вказує на важливу роль окисного стресу в патогенезі післяопераційного гіпопаратиреозу .

3. Перспективним напрямком комплексної терапії хворих з ознаками післяопераційного гіпопаратиреозу є застосування препаратів 3 антиоксидантною дією.

\section{Література}

1. Бєленічев І.Ф. Антиоксиданти: сучасні уявлення, перспектив створення / І.Ф. Бєленічева, С.І. Коваленко, В.В. Дунаєв // Ліки. - 2005. - № 1-2. - С. 43-47.

2. Брейдо И.С. Хирургическое лечение заболеваний щитовидной железы / И.С. Брейдо. - СПб.: Гиппократ, 2008. - С. 336-354.

3. Буряк О.Г. Діагностична значимість показників окисної модифікації білків у діагностиці дихальної недостатності в новонароджених при критичних станах / О.Г. Буряк, Ю.Б. Ященко / Современная педиатрия. 2011. - № 6. - C. 100-102.

4. Денисенко О.І. Окисна модифікація білків як чинник патогенезу алергодерматозів / О.І. Денисенко // Укр. ж. дерматол., венерол. та косметол. - 2004. - № 1. C. 23-26.

5. Зенкова А.В. Состояние функции околощитовидных желез до и после хирургического лечения заболеваний щитовидной железы / А.В. Зенкова // Вестн. ОГУ. 2010. - № 6. - C. 74-77.

6. Зинь А. Прооксидантно-антиоксидантний гомеостаз i мембранний транспорт у живих організмах / А. Зинь // Вісн. Львів. ун-ту. Серія біологічна. - 2012. - Вип. 60. - C. 21-36.

7. Калинина А.П. Методы визуализации околощитовидных желез и паратиреоидная хирургия: руководство для врачей / А.П. Калинина. - М: ВИДАР-М, 2010. $311 \mathrm{c}$.

8. Камышнев B.C. Справочник по клиникобиохимическим исследованиям и лабораторной диагностике / В.С. Камышнев. - М., 2004. - С. 476.

9. Кузнецов Н.С. Предикторы послеоперационного гипопаратиреоза после тиреоидэктомии и методы его лече- 
ния / Н.С. Кузнецов, О.В. Симакина, И.В. Ким // Клин. и эксперим. тиреодол. - 2012. - № 2. - С. 20-27.

10. Ляхович В.В. Активная защита при окислительном стрессе. Антиоксидант-респонсивный элемент / В.В. Ляхович, В.А. Вавилин, Н.К. Зенков // Биохимия. - 2006. - Т. 71, вып. 9. - С. 1183-1197.

11. Полянська О.С. Окисна модифікація білків крові у хворих на ішемічну хворобу серця на тлі фізичної реабілітації / О.С. Полянська, І.Ф. Мещишен, Т.В. Куртян // Бук. мед. вісник. - 2008. - № 4. - С. 50-54.
12. Рибаков С.Й. Тиреоїдна хірургія / С.Й. Рибаков, В.О. Шидловський. - Тернопіль: ТДМУ Укрмедкнига, 2008. -424 c.

13. Complications of thyroid surgery / D.B. de Roy van Zuidewijn [et al.] // Ann. Surg. Oncol. - 2010. - Vol. 2. P. 56-60.

14. Guidelines for complications after thyroid surgery: pitfalls in diagnosis and advices for continuous quality improvement / C. Bures, T. Klatte, G. Friedrich [et al.] // Eur Surg. - 2014. - № 46. - P. 38-47.

\title{
ИЗУЧЕНИЯ УРОВНЯ ПРОДУКТОВ ОКИСЛИТЕЛЬНОЙ МОДИФИКАЦИИ БЕЛКОВ И ФЕРМЕНТОВ АНТИОКСИДАНТНОЙ ЗАЩИТЫ У БОЛЬНЫХ С ПОСЛЕОПЕРАЦИОННЫМ ГИПОПАРАТИРЕОЗОМ
}

\begin{abstract}
А.Я. Пасько
Резюме. В основу исследования положены результаты комплексного обследования и лечения 70 человек с различной патологией щитовидной железы (Щ3), которые находились на стационарном лечении в хирургическом отделении Ивано-Франковской центральной городской клинической больницы и в Ивано-Франковском областном онкологическом диспансере с 2013 по 2016 годы. Всем больным проводили определение уровней паратгормона, общего и ионизированного кальция, определяли оптическую плотность продуктов окисной модификации белков (ОМБ), активность ферментов антиоксидантной системы (АОС) каталазы и супероксиддисмутазы.

В послеоперационном периоде у больных, оперированных по поводу заболеваний щитовидной железы, наблюдается повышение продуктов ОМБ на фоне снижения ферментов АОЗ. Установлено, что дисбаланс системы ОМБ-АОЗ углубляется у больных с наличием признаков гипопаратиреоза (ГПТ). Установлено, что максимальное повышение продуктов ОМБ происходит у больных в 1-е сутки послеоперационного периода, тогда как максимальное снижение ферментов АОЗ отмечается у больных на 6-7-е сутки, что указывает на важную роль окислительного стресса в патогенезе послеоперационного ГПТ. Перспективным направлением комплексной терапии больных с признаками послеоперационного ГПТ является применение препаратов с антиоксидантным действием.

Ключевые слова: операции на щитовидной железе, гипопаратиреоз, окислительная модификация белков, каталаза, супероксиддисмутаза.

\section{STUDY OF PRODUCTS OXIDATIVE MODIFICATION OF PROTEINS AND ANTIOXIDANT ENZYMES IN PATIENTS WITH POSTOPERATIVE HYPOPARATHYROIDISM}

\section{A.Ya. Pasko}

Abstract. The study is based on the results of a comprehensive examination and treatment of 70 people with various thyroid disorders who had been admitted to the surgical department of the Ivano-Frankivsk City Central Hospital and Ivano-Frankivsk Regional Oncology Center from 2013 to 2016. All patients underwent determination of the levels of parathyroid hormone, total and ionized calcium measured optical density products of oxidative modification of proteins (OMP), antioxidant system (AOS) enzyme activity of catalase and superoxide dismutase.

In the postoperative period the patients who were operated on thyroid disease showed an increase in products of OMP and a decrease in antioxidant enzymes. It was established that the system imbalance OMP-AOS deepened in patients with signs of hypoparathyroidism. It was established that maximum increase in products of OMP occurs in patients on the $1 \mathrm{st}$ postoperative day, whereas the maximum reduction AOS enzymes was observed in patients on the 6-7 days, indicating the important role of oxidative stress in the pathogenesis of postoperative HPT. One promising field of adjuvant therapy of patients with signs of postoperative HPT is the use of drugs with antioxidant action.

Key words: surgery on the thyroid, hypoparathyroidism, oxidative modification of proteins, catalase, superoxide dismutase.

HSEI "National Medical University” (Ivano-Frankivsk) 